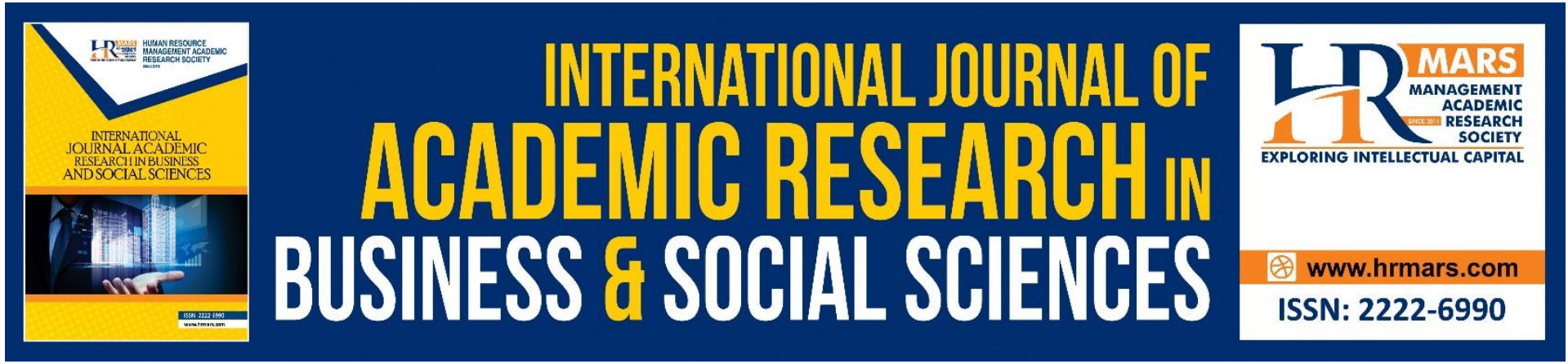

\title{
The Impact of Human Resources Management Practices (HRMPs) on Job Burnout among Faculty Members in Public and Private Universities in Jordan
}

Haitham Ali Hijazi, Dalal M. Al-Zoubi, Shehadeh Al-Gharaibah, Asaad Alsakarneh, Tharwat Al-Hawamdeh

To Link this Article: http://dx.doi.org/10.6007/IJARBSS/v11-i7/10035

DOI:10.6007/IJARBSS/v11-i7/10035

Received: 19 May 2021, Revised: 21 June 2021, Accepted: 12 July 2021

Published Online: 27 July 2021

In-Text Citation: (Hijazi et al., 2021)

To Cite this Article: Hijazi, H. A., Al-Zoubi, D. M., Al-Gharaibah, S., Alsakarneh, A., \& Al-Hawamdeh, T. (2021). The Impact of Human Resources Management Practices (HRMPs) on Job Burnout among Faculty Members in Public and Private Universities in Jordan. International Journal of Academic Research in Business and Social Sciences, 11(7), 789-813.

Copyright: (c) 2021 The Author(s)

Published by Human Resource Management Academic Research Society (www.hrmars.com)

This article is published under the Creative Commons Attribution (CC BY 4.0) license. Anyone may reproduce, distribute, translate and create derivative works of this article (for both commercial and non-commercial purposes), subject to full attribution to the original publication and authors. The full terms of this license may be seen

at: http://creativecommons.org/licences/by/4.0/legalcode

Vol. 11, No. 7, 2021, Pg. 789 - 813

Full Terms \& Conditions of access and use can be found at http://hrmars.com/index.php/pages/detail/publication-ethics 


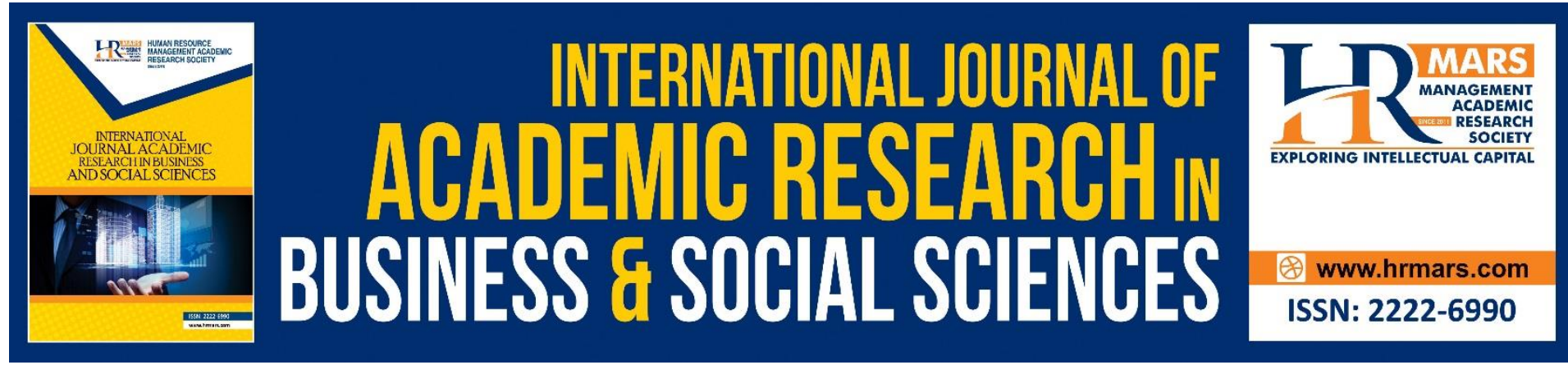

\title{
The Impact of Human Resources Management Practices (HRMPs) on Job Burnout among Faculty Members in Public and Private Universities in Jordan
}

\author{
Haitham Ali Hijazi \\ Assistant Professor, Department of Business, Jerash University, Jordan \\ Email: info@hijazi-km.com
}

Dalal M. Al-Zoubi

Professor, Department of Education, Al-Balqa Applied University, Jordan.

Email: dalal.zoubi@bau.edu.jo

\section{Shehadeh Al-Gharaibah, Asaad Alsakarneh, Tharwat Al- Hawamdeh \\ Associate Professor, Department of Business, Jerash University, Jordan \\ Email: shehadehgh75@gmail.com, asaadalsakarneh@yahoo.com, \\ tharwat_alhawamdeh@yahoo.com}

\begin{abstract}
This study aimed to identify the impact of human resources management practices on job burnout among faculty members of various academic ranks working in public and private universities in Jordan, as well as knowing the percentage of faculty members who would like to leave their universities if they had the opportunity to work in another university. (305) questionnaires were analyzed out of (375) distributed ones, forming the study sample.

The study found that the overall level of human resources management practices and the overall level of job burnout feeling were moderate. And that human resources management practices has an impact on the feeling of job burnout among faculty members. The results also showed that job burnout among faculty members in private universities is slightly higher than their counterparts in public universities. The study revealed that $(50.5 \%)$ of the respondents will consider leaving their universities if they had the opportunity to work in another university, because of their job burnout feeling due to human resources management practices applied in their universities. The study highly recommended the development and improvement of human resources management practices in Jordanian public and private universities.
\end{abstract}

Keywords: Human Resources Management Practices, Job Burnout, Teaching Faculty, Jordanian Universities. 


\section{Introduction}

In light of the rapid developments and changes that the world is experiencing today, all organizations, regardless of their size, nature of work, and field, make great efforts to achieve their goals, sustain their work, and survive in a changing world. Studies indicate that human resources working in organizations are considered the essential and key resource that can help organizations achieve their goals by achieving competitive advantage (Noe et al., 2017). Universities, like other organizations, strive to fulfill their mission of education, scientific research, and community service, especially as they are responsible for creating human and intellectual capital that will bear the responsibility of achieving sustainable development. Consequently, a university's success in achieving its goals, survival, and competitive advantage, depends not only on the financial, material, and technological resources it possesses but also on its human resources that are able to maximize the value of other resources and achieve the university's mission. The most suitable way through which human resources can be turned into a significant source to achieve competitive advantage is for organizations to build a human capital pool that gives them the ability to adapt to the external environment's requirements, which is a core task for the human resources management as an organizational unit, that can be done through the application of human resources management practices correctly. This enables the organization to obtain distinguished human resources, employ them, care for them, and provide them with the appropriate work environment by avoiding everything that can lead to a decline in these resources' performance and lead to a feeling of job burnout (Hijazi \& Jawad, 2008, 70).

Jordan realized the importance of human resources and their vital role in achieving comprehensive and sustainable development a long time ago, so it gave the higher education sector utmost importance to enable it to work efficiently and effectively to assure that the sector outputs are distinguished and able to fill the shortfall in the local and regional labor market. This interest was materialized by establishing the first public university in Jordan in 1962 and the first private university in 1990. Between 1962 and 2021, the number of universities operating in Jordan reached (34) universities between public, private, regional, and ones that are established under a special law. The number of students enrolled in these universities and currently studying is (349.426) students, whereas, the number of administrative members working in various universities is (20.376) employees. The number of faculty members in all universities is (11.394) from various academic ranks (Professor, Associate Professor, Assistant Professor, and Lecturers) distributed over (22) fields of study (Ministry of Higher Education, 2021).

\section{Research Problem}

Researchers have noticed during their work in public and private universities that the human resources department lack sufficient interest in the faculty members working in those universities, whether in terms of the recruitment process, selection, and appointment, training and development, managing compensations, or even planning social welfare activity for the members and retain them, where most of these practices are not institutionalized. Researchers also noted, through their experience and the experiences of their counterparts, that the failure to implement HRMPs in a standardized and correct manner might have led some members to feel emotionally exhausted and unwilling to realize any accomplishments. When researchers referred to literature related to this subject, they found that most studies related to HRMPs have examined the effect of those practices on employee performance, organizational performance, job satisfaction, and senior workers' retention. Whereas the 
studies that dealt with job burnout have examined the reasons behind this phenomenon, like work pressure, job quality, and demographic factors. This inspired the researchers to study the impact of HRMPs on job burnout among faculty members working in Jordanian universities.

Accordingly, the research problem represents the following main question: "What is the impact of human resources management practices on job burnout among faculty members in public and private Jordanian universities?"

The following questions and hypotheses emerge from this question:

\section{Questions}

The first question: What is the level of human resources management practices in Jordanian public and private universities?

The second question: What is the level of job burnout among faculty members in Jordanian public and private universities?

The third question: Do you think of leaving the university if you get the opportunity to work in another university?

\section{Hypotheses}

First hypothesis: at a significance level of $(\alpha \leq .05)$ there is no statistically significant effect of the level of human resources management practices on the level of job burnout for faculty members working in public and private universities in Jordan.

Second hypothesis: at a significance level of $(\alpha \leq .05)$ there are no statistically significant differences in the level of human resources management practices in public and private universities in Jordan that are due to the variables of "gender, academic qualification, academic rank, university, and years of experience" for the sample members.

The third hypothesis: at a significance level of $(\alpha \leq .05)$ there are no statistically significant differences in the level of job burnout among faculty members working in public and private universities in Jordan that are due to the variables of "gender, educational qualification, academic rank, university, and years of experience" for the sample members.

\section{Research Objectives}

Based on the research questions and hypotheses, the research aims to achieve the following objectives:

1- Identify the level of HRMPs in Jordanian public and private universities for the following dimensions: human resources planning, recruitment, selection and appointment, performance evaluation, training and development, salary and compensation, and retention of human resources.

2- Identify the level of job burnout among faculty members in Jordanian public and private universities.

3- Identify the sample members' perspective on the possibility of leaving work at the university in which they work, if they had the opportunity to work in another university.

4- Identify the impact of HRMPs, in their dimensions, on faculty members' job burnout in public and private Jordanian universities.

5- Identify the differences in the level of HRMPs, in their dimensions, in both public and private Jordanian universities based on the variables of gender, educational qualification, academic rank, university, and years of experience. 
6- Identify the differences in the level of job burnout, in its dimensions, in both public and private Jordanian universities based on the variables of gender, educational qualification, academic rank, university, and years of experience.

\section{Research Importance}

The research importance emerged from the importance of the study variables and from the benefit that public and private universities are expected to obtain. The lack of research that studied HRMPs on job burnout among faculty members in public and private universities in general, and in Jordan in particular, gives this research distinct importance. Moreover, this research deals with a critical topic in terms of modern administrative trends, which pays close attention to the issue of human resources, starting from the planning stage and ending with the retention stage, given its importance in enabling and helping organizations achieve their goals and survive in a dynamic world. Job burnout is also receiving the attention of researchers and decision-makers in all organizations due to the possible adverse effects on human resources working in organizations and what negatively affects their performance, and thus, on organizational performance in general and their competitive position.

\section{Background}

\section{Human Resources Management Practices}

Human resources management is considered one of the most critical departments in the organization, where all functions in the organization depend primarily on the efficiency, sincerity, and enthusiasm of its employees. Therefore, human resources management has acquired a different level of importance as it is the main element around which the work revolves. It is considered the element that cannot be imitated, and hence, through which a highly competitive advantage can be achieved for the organization.

There are many definitions of human resources management, where Dessler $(2011,108)$ defined it as "the process of acquiring, training, evaluating, and compensating employees and paying attention to the occupational health and safety factors related to work". As for Mondy (2012) defined it as "the use of individuals to achieve organizational goals".

Human resources management practices or the so-called human resources management functions are considered a group of activities and the implementation of special plans developed for the human resources management, aiming primarily to achieve the objectives of both employees and the organization (Al-Afif, 2018, 83). Among the most important practices are:

Work Analysis and Design: It is an organized process that aims to collect all information related to the work to determine the duties and responsibilities assigned to a job, in addition to identifying the certificates, skills, and experiences (competencies) required for the job holder. It also entails designing the work in an effective motivational manner. Work analysis is carried out when the organization is established, or when a new job appears within the organization, or when the work is changed due to technological conditions, business partnerships, or other reasons.

Among the most important outputs of work analysis is Job Description, which includes the tasks, duties, and responsibilities involved in the job, and job specification, which includes the knowledge, skills, abilities, and personal characteristics that must be met by the person who will take the job. Many researchers believe that work analysis is extremely important for 
human resources and that it provides the basis on which all components of the human resources management system are built (Harem, 2020, 35).

Human resources Planning: As Dessler (2011) states, it is the first and most important function of human resources management, and the cornerstone of what the organization will build on, whether it is success or failure. Daft (2007) defined it as "the administrative function that is related to defining the organization's future goals, and the tasks and resources required to achieve those goals". Thus, human resources planning means determining the future needs of human resources, in quantity and quality, through forecasting the need or the demand and supply of the human resources.

Hiring (Recruitment, Selection, Appointment): Organizations pay great attention to the process of recruiting, selection, and appointment to ensure the continuation of the organization's operations. This includes recruiting from within or from outside the organization. The recruiting process aims to provide the appropriate number of human resources, attract distinct and appropriate competencies, achieve stability for workers, and meet the social and legal responsibility requirement for the job (Al-Afif, 2018, 85). The hiring process is the natural extension of the human resources planning process, which is considered one of the most important jobs because it is related to the efficiency of the workforce, which is reflected in the organization's performance, its distinction, and its ability to compete.

Training and Development: are defined as the efforts that aim to provide workers in the organization with knowledge and skills related to the work that they do in the present, and develop their capabilities for the future, which is achieved through training and development (Ahmed, 2019, 562). The training and development process aims to increase productivity, enhance institutional performance, develop leadership styles, support the realism of performance, document the relationship between management and workers, and develop employees' capabilities to deal with customers and adapt to changes (Al-Afif, 2018, 86; Harem, 2020, 36).

Employees' Performance Evaluation: Yee \& Chen defined performance evaluation as "that process that includes setting work standards, comparing actual work performance with those standards, and providing feedback to the employee about his performance to motivate him and correct deviations" (Ibrahim \& Al Wakeel, 2020, 125). The performance evaluation aims to provide decision-makers with information on the performance of employees, estimate the appropriate financial rewards, and evaluate and reveal the capabilities of the employees, which contributes to the improvement of employee performance levels, employees' relations, and the development of the organization's performance (Al-Gharibah, 2009, 20).

Compensations: Compensations include both material and non-material compensations. Material compensations include salaries, wages, and incentives, whereas non-material compensations include social and health benefits. Compensations enhance the employees' sense of comfort and stability which reflects positively on their performance (Al-Afif, 2018, 86). Direct and indirect salaries, wages, and benefits play a significant role in incentivizing workers and increasing their motivation to work and belonging to the organization, especially if these compensations are directly and equitably linked to their performance (Harem, 2020, 37). 
Industrial Relations and Collective Bargaining: There are additional responsibilities for human resources management that appeared with trade unions' emergence, where it became the Human Resources Department's duty to negotiate, run dialogue sessions, and discuss with the unions many issues related to work contracts and employees' privileges and rights (Harem, 2020, 37).

Commitment to The Relevant Government Legislations: There are many government legislations related to personnel affairs, such as the right to equal opportunities, minimum wages, workers' safety, participation in social security, health insurance, security approvals for hiring, and others. The matter that calls for Human Resources Department to adhere to these instructions and legislation and follow them on an ongoing basis (Harem, 2020, 38)

Retaining Human Resources: As the importance of human capital and its main role in achieving competitive advantage increased, the human resources department now has an important function, that is maintaining distinguished human resources, paying attention to workers with rare specializations, and reducing the turnover rate and retain employees (Kasasbeh et al., 2010, 165).

Studies indicate that the application of human resource management practices in educational organizations such as universities and public and private institutes brings many positive results such as improving employees' performance which reflects on the organizational performance in terms of employees' performance levels and thus the organizational performance levels in general (Eneizan et al., 2021; Alsakarneh, 2019; Saifalislam et al., 2014; Amin et al., 2014). Studies have also indicated that the application of human resource management practices in universities helps improve the university rank (Ashraf et al., 2014), retain senior employees (Kosi et al., 2015; Hong et al., 2012), and raise job satisfaction levels among faculty members (Mumtaz et. al., 2011). In addition, universities that apply human resource management practices achieve benefits than other universities, the ones that do not apply such practices, can't achieve, such as obtaining grants for conducting research, increasing the number of scientific publications, as well as a noticeable increase in obtaining distinguished scientific research awards, and deepening the level of international cooperation with relevant organizations (Ojokuku \& Akanbi, 2015). Nevertheless, studies have indicated that there is a variation and difference in the level of application of human resource management practices between universities around the world (Mattjik et al., 2020; Allui \& Sahni, 2016; Abu Teir \& Zhang, 2016; lqbal et al., 2011).

\section{Job Burnout}

The phenomenon of job burnout has caught the attention of many researchers in the modern era, as it became one of the most common research topics in psychology and occupational health, where studies have shown that workers who suffer from job burnout face lifethreatening health problems (Melhem, 2020, 61).

Opinions diverged on the concept of job burnout, where Freudenberg, an American psychoanalyst, was the first to introduce the term "Job Burnout" into the academic field. One of the most common definitions is that of Maslach \& Jackson $(1981,109)$, who define job burnout as "an individual's sense of emotional stress, dulled feelings, and decreased personal accomplishment." While Al-Kelabi \& Rasheed define it as "a state of emotional, intellectual, and physical exhaustion that takes the form of expressions that the individual uses towards his work" (Al-Talbani et. al., 2015, 703). 


\section{Job Burnout Dimensions}

A study by Maslach \& Jackson (1981) indicated the existence of three job burnout dimensions: Emotional Exhaustion: It is the worker's loss of self-confidence and morale, and the exhaustion of his total energy with the accompanying frustration and psychological tension, where the worker has a general feeling of extreme fatigue as a result of the workloads and responsibilities required of him

Depersonalization: By taking negative attitudes towards the individuals who receive the service and not caring for them, and dealing with others as an inanimate object and not as a human being, where cruelty, brutality, indifference, frequent criticism and accusation of others, and criticism of human values and feelings appear.

Lack of Personal Accomplishment: The individual tends to evaluate himself negatively, and feel a drop in his performance efficiency and effectiveness or in his relation with others.

\section{Job Burnout Causes}

There are several causes of job burnout resulting from three dimensions. Cherniss (referred to in Al-Telbani et. al, 2015, 703) has identified them as follows: A) The Individual Dimension: many studies have confirmed that the employee who is most affiliated and devoted to his work is the most vulnerable to job burnout. This is due to his inability to achieve his goals and accomplish the work to the degree and level he wants due to the pressures exerted on him. B) The Social Dimension: where the employees whose work requires direct contact with clients are most likely to feel burned out, because of the pressures on them and their continuous attempts to satisfy customers. C) The Professional Dimension: are the reasons related to work conditions and its composition, where work conditions and composition contribute to the increase or decrease in work pressures on the employee which negatively reflects on the employee's inability to achieve his goals and makes him feel burnout.

Many studies have been conducted with the aim of investigating the levels of job burnout in university environments among faculty members in an attempt to find out whether this phenomenon exists among university faculty members, try to understand it, explain its dimensions, and reach solutions that help reduce it, if it does exist. These studies have found that faculty members in universities do suffer from job burnout phenomenon and that there is a relationship between the demographic factors for these members and their job burnout, even if it was to varying degrees with regards to the burnout levels or the different demographic factors (Jia et. al., 2017; Manzor, et. al., 2019; Toker, 2011; Khdour et. al., 2015; Bin Zaid, 2019). Other studies also found that there is a relationship between job burnout levels and academic ranks held by faculty members, and that these levels differ according to the academic rank (Azeem \& Nazir, 2008; Toker, 2011). In addition, a study by Padilla \& Thompson (2016) found that low social and family support, lack of sleep, and limited leisure and entertainment times are associated with high levels of job burnout, while a study by Garcia-Arroyo and Osca (2019) found a positive association between job burnout, overwork, and elusive style. Reddy \& Poornima (2012) observed a relationship between work stress and job burnout, as well as between perceived stress and job burnout (Teles et., al., 2017). The study by Al-Azizi (2020) found that a decrease in the career path quality leads to an increase in job burnout levels, while Koohi study (2020) found a relationship between social capital, psychological capital, and organizational climate, and the emergence of job burnout phenomenon. While (Ozturk, 2013) concluded that the existence of some institutional problems, student problems, and workload leads to a feeling of job burnout. In spite of this, a study by Azeem (2010) found that job burnout could lead to personality hardiness 
phenomenon, as well as job involvement. As for job burnout levels of university faculty members, studies have found that there are varying levels of job burnout among these members (Amir, 2020; Koohi, 2020; Guillen et. al., 2019; Mansourian et. al., 2019; Kebde \& Gedfie, 2018; Aslan \& Bektas, 2016).

\section{Research Methodology}

\section{a. Research Approach}

This study is a causal study, where it followed a descriptive-analytical approach to achieve its objectives. It is descriptive because it describes the status and level of human resources practices in Jordanian public and private universities and job burnout. It is also analytical as it studies the impact of HRMPs on job burnout among faculty members in Jordanian public and private universities.

\section{b. Research Population and Sample}

The study population consists of all faculty members working in Jordanian public and private universities, a total of (11394). The analysis unit included all the academic ranks working in the mentioned universities (professor, associate professor, assistant professor, and lecturer). Accordingly, the study sample consisted of (375) faculty members, which are considered appropriate according to statistical methods (Sekaran and Bougie, 2016). Therefore, (375) questionnaires were distributed. (320) questionnaires were returned and (15) forms were excluded due to non-validity issues, resulting in a final number of (305) questionnaires suitable for statistical analysis, noting that the study sample was a stratified random sample according to the university variable.

\section{Description Sample Characteristics}

This section aims to clarify the personal and professional characteristics of the study sample in terms of the following variables: gender, educational qualification, academic rank, university (public/private), and years of experience, as shown in Table (1). 
Table 1

Characteristics of the study sample

\begin{tabular}{|c|c|c|c|}
\hline \multicolumn{2}{|l|}{ Variables } & \multirow{2}{*}{$\frac{\text { No. }}{240}$} & \multirow{2}{*}{$\frac{\%}{78.7}$} \\
\hline Gender & Female & & \\
\hline & Male & 65 & 21.3 \\
\hline & Total & 305 & 100.0 \\
\hline \multirow[t]{3}{*}{ Qualification } & PhD & 280 & 91.8 \\
\hline & Master & 25 & 8.2 \\
\hline & Total & 305 & 100.0 \\
\hline \multirow[t]{5}{*}{ Academic Rank } & Full professor & 33 & 10.8 \\
\hline & Associate professor & 104 & 34.1 \\
\hline & Assistant professor & 104 & 34.1 \\
\hline & Lecturer & 44 & 14.4 \\
\hline & Total & 305 & 100.0 \\
\hline \multirow[t]{3}{*}{ University } & Public & 116 & 38.0 \\
\hline & Private & 189 & 62.0 \\
\hline & Total & 305 & 100.0 \\
\hline \multirow[t]{5}{*}{ Experience } & Less than 5 years & 54 & 17.7 \\
\hline & 5- less than 10 years & 102 & 33.4 \\
\hline & 10- less than 15 years & 80 & 26.2 \\
\hline & 15 years and more & 69 & 22.6 \\
\hline & Total & 305 & 100.0 \\
\hline
\end{tabular}

The above Table shows that $78.7 \%$ of the sample is females, and the rest is males. Also, it is found that $91.8 \%$ of the sample has got a Ph.D. degree, followed by those who have earned a Master's degree.

Also, it is found that $40.7 \%$ of the sample is assistant professors, followed by $34.1 \%$ of the sample is an associate professor.

Also, it is found that $62 \%$ of the sample is working in private universities, and the rest is working in public universities. Also, it is found that $33.4 \%$ have experienced between 5 - less than ten years, whereas $26.2 \%$ of the sample has experience between 10 - less than 15 years. 


\section{Research Tools}

This study relied on two primary sources to collect the required data: secondary sources and primary sources represented by the questionnaire that was designed to achieve the research objectives. The design of the research tool (the questionnaire) was based on previous literature, especially the part related to job burnout, where the job burnout measure that was developed by Maslach (Maslach \& Jackson, 1981) was Arabized, whereas the researchers built the section related to HRMPs. The questionnaire consisted of (55) paragraphs that measured two dimensions of HRMPs and job burnout, as follows:

Table 2

Distribution of the paragraphs of the study questionnaire

\begin{tabular}{|l|l|}
\hline Measures and Dimensions & \# Paragraphs \\
\hline Human Resources Management Practices Measure & \\
\hline Human Resources Planning & 6 \\
\hline Recruitment, Selection, and Appointment & 5 \\
\hline Faculty Members Evaluation & 7 \\
\hline Training and Development & 6 \\
\hline Salary and Compensation & 7 \\
\hline Retention of Human Resources & 4 \\
\hline Job Burnout Measure & \\
\hline Emotional Exhaustion & 7 \\
\hline Depersonalization & 5 \\
\hline personal accomplishment & 8 \\
\hline Total & 55 \\
\hline
\end{tabular}

A question was added at the end of the questionnaire in order to find out whether the study sample members are considering leaving the university if they are given an opportunity to work in another university.

\section{Normal Distribution Test}

Multi collinearity between independent variables was tested as shown in table (3). It is found that VIF values are less acceptable cutoff values (10). Whereas the Tolerance values are less than the acceptable cutoff value (0.10). 
Table 3

Collinearity statistics test

\begin{tabular}{|l|l|l|}
\hline \multirow{2}{*}{ Model } & \multicolumn{2}{|l|}{ Collinearity Statistics } \\
\cline { 2 - 3 } & Tolerance & VIF \\
\hline Human Resources Planning & .322 & 3.109 \\
\hline Recruitment, Selection, and appointment & .424 & 2.360 \\
\hline Performance Evaluation & .293 & 3.411 \\
\hline Training and Development & .513 & 1.949 \\
\hline Salaries and Compensation & .573 & 1.744 \\
\hline Retention of Human Resources & .664 & 1.507 \\
\hline Human Resources Planning & .322 & 3.109 \\
\hline
\end{tabular}

\section{Validity and Reliability of Research Tools}

\section{Validity Test}

In order to examine the validity of the research tools, the questionnaire was presented to a number of specialized referees in order to ensure the clarity of the paragraphs of the questionnaire and the ability to understand them. Based on the notes received, the required adjustments were made.

\section{Reliability Test}

Cronbach Alpha was used to test the consistency of the questionnaire. The following table (4) shows that Alpha value for each variable is greater than the accepted value (0.60) that reflects the consistency of the questionnaire (Sekaran \& Bougie,2016)

Table 4

Consistency of research Tools (Cronbach Alpha)

\begin{tabular}{|l|l|}
\hline Variable & Alpha value \\
\hline Human Resources Planning & 0.886 \\
\hline Recruitment, Selection, and Appointment & 0.906 \\
\hline Performance Evaluation & 0.922 \\
\hline Training and Development & 0.931 \\
\hline Salaries and Compensation & 0.916 \\
\hline Retention of Human Resources & 0.81 \\
\hline Job Burnout & 0.833 \\
\hline
\end{tabular}




\section{Correction of the Study Tools}

In order to calculate the total score for each measure, five options have been set. The respondent chooses one of these options that express his opinion, which ranges from 1 to 5 . To judge the level of the arithmetic means of the paragraphs and fields for both measures in the tool, the statistical norm is adopted using the following equation:

Upper limit of the measure (5) - Lower limit of the measure (1) / Number of required classes Number of required classes (3)

$(5-1) / 3=1.33$

And then add the answer (1.33) to the end of each category.

\begin{tabular}{|l|l|}
\hline Arithmetic Average & Level \\
\hline from 1.00- 2.33 & Low \\
\hline from 2.34- 3.67 & Moderate \\
\hline from 3.68- 5.00 & High \\
\hline
\end{tabular}

\section{Research Variables}

This study consisted of several variables as follows:

- The independent variable: the level of human resources management practices in its dimensions (human resources planning, recruitment, selection and appointment, evaluation of faculty members, training and development, salaries and compensation, retention of human resources) in public and private universities.

- - The dependent variable: the level of job burnout in its dimensions (emotional exhaustion, depersonalization, personal accomplishment) among faculty members in public and private universities.

Secondary (intermediate) independent variables:

- Gender: Male, female

- Qualification: PhD, Master

- Academic Rank: Professor, Associate, Assistant, lecturer.

- University: Public, Private.

- Experience: Less than 5 years, 5- less than 10 years, 10- less than 15 years, 15 years and more.

\section{Statistical Methods Used}

To answer the research questions, examine its hypotheses, and arrive at the results and recommendations that achieve the research objectives, the arithmetic means, and standard deviations were used to answer the first and second questions, whereas frequencies and percentages were used to answer the third question. Multiple linear regression analysis was also used to test the first hypothesis while multivariate analysis variance was used to test the second and third hypotheses. 


\section{Data Analysis and Results \\ First question}

"What is the level of human resources management practices in public and private universities?"

Means and standard deviation were used to answer this question as shown in table 5.

Table 5

Means and Std. Deviation (Dimensions of human resources management Practices)

\begin{tabular}{|l|l|l|l|l|l|l|}
\hline Fields & $\mathbf{N}$ & $\begin{array}{l}\text { Minimu } \\
\mathbf{m}\end{array}$ & $\begin{array}{l}\text { Maximu } \\
\mathbf{m}\end{array}$ & $\begin{array}{l}\text { Mean } \\
\text { Planning }\end{array} 305$ & $\begin{array}{l}\text { Std. } \\
\text { Deviation }\end{array}$ & $\begin{array}{l}\text { Level of } \\
\text { means }\end{array}$ \\
\hline $\begin{array}{l}\text { Recruitment, Selection, \& } \\
\text { appointment }\end{array}$ & 305 & 1.00 & 5.00 & 3.22 & .9608 & Moderate \\
\hline Performance Evaluation & 305 & 1.00 & 5.00 & 3.27 & .8938 & Moderate \\
\hline Training \& development & 305 & 1.00 & 5.00 & 3.02 & .9324 & Moderate \\
\hline Salaries \& compensation & 305 & 1.00 & 5.00 & 2.60 & 1.0026 & Moderate \\
\hline $\begin{array}{l}\text { Preservation of Human } \\
\text { Resources }\end{array}$ & 305 & 1.00 & 5.00 & 2.86 & .93366 & Moderate \\
\hline $\begin{array}{l}\text { Total (Human Resources } \\
\text { Management Practices) }\end{array}$ & $\mathbf{3 0 5}$ & $\mathbf{1 . 0 0}$ & $\mathbf{5 . 0 0}$ & $\mathbf{3 . 1 8}$ & $\mathbf{. 7 7 2 9 1}$ & Moderate \\
\hline
\end{tabular}

It is evident from Table No. (5) that the overall level and the level of HRMPs dimensions in public and private universities were all moderate. It was highest in the field of planning and the lowest in the field of salaries and compensation.

This result indicates insufficient professionalism among the human resources departments in universities with regard to their work performance. Failure of human resources departments to do their job correctly and professionally will be reflected on university employees, including administrators and faculty members, as they are the target group for human resources management, which will ultimately reflect the university performance and its academic reputation in society and labor market, and on its ability to survive and compete with other universities, where any weakness related to the administrative or academic aspect in any university will impact its graduates and the extent to which they can acquire the skills necessary to practice their fields of study in the labor market.

This result calls for questioning the reason why human resources departments in public and private universities do not exercise their duties effectively and professionally enough? The answer to this question may be related to the way universities choose their administrative cadres in the various departments. In both public and private universities, the faculty members are the most important because they are directly linked to the ability to teach a specific discipline successfully, and because of their impact on the surrounding community and on the university's reputation. This interest also comes from the university's need to fulfill the conditions of the Higher Education Accreditation Commission regarding accrediting 
faculty members. As for administrators, universities' focus is often on specific departments such as admission, registration, and accounting, which require high competencies and skills to perform the work properly and avoid mistakes that can lead to disastrous consequences. As for the rest of the departments, including the human resources department, they take the least attention from the university administration. These departments may experience misappropriation of employees in terms of specialization, experience, and competencies, in addition to inappropriate appointments [in terms of job nature] due to nepotism and favoritism, just like appointments in other institutions.

Through the researchers' experience on this subject, given that they work as faculty members in various private and public universities, such practices, whether inappropriate appointments, poor distribution of departments, or the failure to give administrative staff adequate training in their field of work, may have been the most influencing factors for human resources departments inability to practice their work effectively and professionally.

\section{Second Question}

What is the level of job burnout in its dimensions (emotional exhaustion, depersonalization, personal accomplishment) among the faculty members in public and private universities? Means and standard deviation were used to answer this question as shown in table 6.

Table 6

Means and Std. Deviation (Dimensions of job burnout)

\begin{tabular}{|l|c|l|l|l|l|l|}
\hline Fields & $\mathbf{N}$ & $\begin{array}{l}\text { Minimu } \\
\mathrm{m}\end{array}$ & $\begin{array}{l}\text { Maximu } \\
\mathrm{m}\end{array}$ & $\begin{array}{l}\text { Mean } \\
\mathrm{s}\end{array}$ & $\begin{array}{l}\text { Std. } \\
\text { Deviation }\end{array}$ & $\begin{array}{l}\text { Level of } \\
\text { Means }\end{array}$ \\
\hline Emotional exhaustion & 305 & 1.00 & 5.00 & 3.03 & .87280 & Moderate \\
\hline Depersonalization & 305 & 1.00 & 5.00 & 2.13 & .87921 & Low \\
\hline Personal accomplishment & 305 & 1.00 & 5.00 & 3.30 & .49864 & Moderate \\
\hline Total (Job burnout) & $\mathbf{3 0 5}$ & $\mathbf{1 . 0 5}$ & $\mathbf{4 . 4 0}$ & $\mathbf{2 . 9 1}$ & $\mathbf{. 5 1 9 4 0}$ & Moderate \\
\hline
\end{tabular}

It is evident from Table No. (6) that the overall job burnout level among faculty members in public and private universities was moderate. Job burnout was moderate in the emotional exhaustion and personal accomplishment fields, whereas it was low in the field of depersonalization.

This result indicates that the faculty members in public and private universities suffer reasonably from job burnout which cannot be underestimated, especially in the fields of emotional exhaustion and personal accomplishment, which the university administration needs to pay attention to due to its impact on their performance and thus the performance of the university in general.

This result may be explained by the university's failure to give sufficient and appropriate attention and support to faculty members, which is the support and understanding of their feelings and desires regarding work and their relationship with the university, where individuals constantly need emotional support in different situations, including work situations. Individuals feeling that they are supported by those around them, especially if a problem arises that needs help to overcome, makes it easier for them to deal with these 
situations and problems in the best possible way, which consequently affects their mental and physical health, and ultimately affects their general performance. Also, the moderate level of the personal accomplishment field is the most significant proof that the university administration does not provide adequate support to its faculty members. It is the duty of university administration to encourage and motivate faculty members in order to develop, each in his field. If the faculty member does not find proper appreciation and recognition for his efforts, he will feel that what he is doing is insignificant for the university and his accomplishment will decline, without even realizing it.

As for the depersonalization field, which has a low and appropriate result, this may be explained by the faculty members knowledge and education, where each member has a great background that qualified him to achieve his academic rank and thus have the necessary psychological balance that protects him from reaching the point of sagging personal feelings. A faculty member in Jordan is considered one of the most respected professions in society, which has a significant impact on the faculty member's satisfaction with himself and with his job which helps to bring about balances in his feelings and not surrender to negative emotions.

\section{Third Question}

Do you think of leaving the university if you get the opportunity to work in another university? Frequencies and percentages were used to answer this question as shown in table 7.

Table 7

The responses of the study sample

\begin{tabular}{|l|l|l|l|l|}
\hline Answer & Frequency & Percent & Valid Percent & Cumulative Percent \\
\hline No & 151 & 49.5 & 49.5 & 49.5 \\
\hline Yes & 154 & 50.5 & 50.5 & 100.0 \\
\hline Total & 305 & 100.0 & 100.0 & \\
\hline
\end{tabular}

Table No. (7) shows that the number of faculty members who are considering the university if they get the opportunity to work in another university is a little bit more than half (154) individuals (50.5\%). This percentage is considered very high and portends the seriousness of universities' situation. The percentage shows that a vast number of faculty members are not satisfied with working at their current universities, and are waiting for any opportunity to work in another university, hoping it will be better. This dissatisfaction certainly has reasons, where it is often linked to two aspects: the financial aspect and the moral aspect.

As for the financial aspect, the salaries, bonuses, compensation ... etc. of faculty members in both public and private universities are low compared with world countries, so it is natural for a faculty member to think of change, if there is a suitable opportunity in another country, for example. Also, salaries, bonuses, compensation ... etc, in public universities are better than in private universities, so it is expected that a faculty member who works in a private university wants to transfer to a public university. In addition to all of this, there is a differentiation and difference in salaries within the same university, especially in private universities, for the faculty members with the same academic rank according to the difference in specialization or to the university need for this or that individual. All these financial aspects 
must have an effect on the dissatisfaction of the faculty member and thus seeks a better opportunity to improve his financial situation.

As for the moral aspect, the faculty members, like other workers in different sectors, seek to receive appreciation and respect, and want to be dealt with objectively and fairly. They also seek appreciation for their accomplishments, encouragement to carry out scientific research, creativity, and innovation ... etc, and want to be motivated to continue serving their students, the university, and society.

The above result indicates that this large percentage that wants to leave work for a better opportunity is not satisfied with the university administration's way of dealing with them and achieving their desires and needs. This may be because many of the appointments in universities, whether public or private, are unfair and a result of nepotism and social pressure, which often does not stop at this point, but exceeds it to the interference of cronyism within the university. The matters of some members go smoothly and receive superb support in the university, while others have difficulty obtaining their rights such as promotions, carrying out scientific research, participation in seminars, activities, and various committees, appreciation of their competencies, and using their capabilities, which may be reflected in a feeling of dissatisfaction and a desire to change the university in the hope of obtaining the appreciation they deserve. The researchers have touched on this through their work in public and private universities, where complaints about conditions within universities in general exist and in abundance, which was confirmed by the second question result where the total level of job burnout was moderate, which from the researchers' point of view, is considered unacceptable.

\section{First Hypothesis}

"At a significance level of $(0.05 \alpha)$, there is no statistically significant effect of the level of human resources management practices in its dimensions on the level of job burnout for faculty members working in public and private universities in Jordan".

Table 8: Model Summary

\begin{tabular}{|l|l|l|l|l|}
\hline Model & $R$ & R Square & Adjusted R Square & $\begin{array}{l}\text { Std. Error of the } \\
\text { Estimate }\end{array}$ \\
\hline 1 & $.251^{\mathrm{a}}$ & .063 & .044 & .50778 \\
\hline
\end{tabular}

a. Predictors: (Constant), retention, evaluation, salaries, training, recruitment, planning

Table 9: ANOVA

\begin{tabular}{|l|l|l|l|l|l|l|}
\hline \multicolumn{2}{|l|}{ Model } & Sum of Squares & $\mathrm{df}$ & $\begin{array}{l}\text { Mean } \\
\text { Square }\end{array}$ & $\mathrm{F}$ & Sig. \\
\hline \multirow{2}{*}{1} & Regression & 5.176 & 6 & .863 & 3.346 & $.003 \mathrm{~b}$ \\
\cline { 2 - 8 } & Residual & 76.837 & 298 & .258 & & \\
\cline { 2 - 7 } & Total & 82.013 & 304 & & & \\
\hline
\end{tabular}

a. Dependent Variable: burnout 
b. Predictors: (Constant), retention, evaluation, salaries, training, recruitment, planning

Table 10: Regression Coefficient

\begin{tabular}{|c|c|c|c|c|c|c|}
\hline \multirow{2}{*}{\multicolumn{2}{|c|}{ Model }} & \multicolumn{2}{|c|}{$\begin{array}{l}\text { Unstandardized } \\
\text { Coefficients }\end{array}$} & \multirow{2}{*}{$\begin{array}{l}\text { Standardized } \\
\text { Coefficients } \\
\text { Beta }\end{array}$} & \multirow[t]{2}{*}{$\mathrm{t}$} & \multirow[t]{2}{*}{ Sig. } \\
\hline & & B & Std. Error & & & \\
\hline \multirow[t]{7}{*}{1} & (Constant) & 2.831 & .134 & & 21.188 & .000 \\
\hline & planning & -.195 & .058 & -.332 & -3.360 & .001 \\
\hline & recruitment & .116 & .047 & .215 & 2.495 & .013 \\
\hline & evaluation & .114 & .060 & .197 & 1.898 & .059 \\
\hline & training & .061 & .044 & .109 & 1.389 & .166 \\
\hline & salaries & -.069 & .038 & -.133 & -1.795 & .074 \\
\hline & retention & -.007 & .038 & -.013 & -.183 & .855 \\
\hline
\end{tabular}

Linear multiple regression is used to test the above hypothesis, it is found that $r=0.251$ reflects a low significant impact, as well as $r 2=0.063$, which reflects that $6.3 \%$ of the variance in the dependent variable is explained by the independent variables.

Also, it is found that $F$ value $=3.346$ is significant at 0.05 level that means there is a statistically significant effect of the level of human resources management practices in its dimensions (human resources planning, recruitment, selection and appointment, performance evaluation, training and development, salaries and compensation, and retention of human resources) on the level of job burnout for faculty members working in public and private universities in Jordan.

Also, $t$ value for (human resources planning, and recruitment, selection, and appointment) variables are significant at 0.05 level that means it has an impact on the dependent variable. This result of the linear multiple calls for not accepting the null hypothesis and accepting the following alternative hypothesis: "At a significance level of $(0.05 \alpha)$, there is a statistically significant effect of the level of human resources management practices in its dimensions (human resources planning, recruitment, selection and appointment, performance evaluation, training and development, salaries and compensation, and retention of human resources) on the level of job burnout for faculty members working in public and private universities in Jordan".

This result, which indicates that HRMPs have an impact on job burnout among faculty members in public and private universities, is consistent with what was previously mentioned in the answers to the first and second questions, that the overall level of HRMPs was moderate, and that the level of job burnout among faculty members was also moderate. Therefore, the result was expected. As for the percentage of explained variance in the dependent variable, which is the job burnout, it means that $6.3 \%$ of the change or difference in the dependent variable is due to the change in the independent variable (HRMPs), whereas the rest of the percentage may be explained by other variables such as, job satisfaction level, the administration's style of dealing with faculty members, the prevailing organizational environment in the university, corporate culture, personal factors..... etc. Although this percentage is not high, it is statistically significant as indicated by the variance analysis table, which means that this effect has real meaning and is not a coincidence. This effect may have stemmed from the fact that the tasks performed by human resources departments directly 
affect faculty members, whether In planning, recruitment, or training ... etc., and that any lack from the human resources management in performing its tasks will probably result in more feelings of emotional exhaustion or personal accomplishment among faculty members. It is also evident from Table 10, that the Beta values for all fields ranged between moderate to low and that only two of them had statistical significance, meaning that the correlation between these two fields [Planning and Recruitment, Selection \& Appointment] and job burnout is present and is of statistical significance, where it was at a moderate level for the Planning, and a low level for Recruitment, Selection \& Appointment.

\section{Second Hypothesis}

At a significance level of $(0.05 \alpha)$, there are no statistically significant differences in the level of human resources management practices in public and private universities in Jordan that are due to the variables of "gender, academic qualification, academic rank, university, and years of experience" for the sample members.

Table 11: Tests of Between-Subjects Effects

\begin{tabular}{|l|l|l|l|l|l|}
\hline Source & $\begin{array}{l}\text { Type III Sum of } \\
\text { Squares }\end{array}$ & df & $\begin{array}{l}\text { Mean } \\
\text { Square }\end{array}$ & F & Sig. \\
\hline Corrected Model & $2.961 \mathrm{a}$ & 5 & .592 & 1.150 & .334 \\
\hline Intercept & 21.094 & 1 & 21.094 & 40.974 & .000 \\
\hline Gender & .245 & 1 & .245 & .476 & .491 \\
\hline Academic qualification & .302 & 1 & .302 & .586 & .445 \\
\hline Academic rank & 1.288 & 1 & 1.288 & 2.502 & .115 \\
\hline University & 1.317 & 1 & 1.317 & 2.559 & .111 \\
\hline Years of experience & .273 & 1 & .273 & .531 & .467 \\
\hline Error & 153.929 & 299 & .515 & & \\
\hline Total & 2996.985 & 305 & & & \\
\hline Corrected Total & 156.890 & 304 & & & \\
\hline
\end{tabular}

a. R Squared $=.019$ (Adjusted R Squared $=.002$ )

ANCOVA test is used to test the above hypothesis, it is found that the $F$ value for each variable is not significant at 0.05 level, which means there are no statistically significant differences in the level of human resources management practices in public and private universities in Jordan that are due to the variables of "gender, academic qualification, academic rank, university, and years of experience" for the sample members.

This result indicates that faculty members' perspectives on the level at which human resources management practices their tasks were similar regardless of the differences between them, whether in terms of gender, academic qualification... etc, which means that there is a consensus on the level of these practices. This gives a clear indication of the moderate level of HRMPs in public and private universities. This consent in the perspectives of the sample members may be due to the fact that faculty members are the ones who are directly affected by HRMPs, where the main task of human resources management is handling the affairs of faculty members, starting from the stage preceding the appointment up to the stage where a faculty member leaves the university, whether by retirement, resignation, or any other reason. Therefore, faculty members' evaluations are varied depending on the periods and missions that linked them to human resources management. This result indicates that faculty members' satisfaction with the performance of human resources management, 
despite the differences in their ranks, is not absolute or significant in public and private universities.

\section{The third hypothesis}

At a significance level of $(0.05 \alpha)$, there are no statistically significant differences in the level of job burnout among faculty members working in public and private universities in Jordan that are due to the variables of "gender, academic qualification, academic rank, university, and years of experience" for the sample members.

Table 12: Tests of Between-Subjects Effects

Dependent Variable: burnout

\begin{tabular}{|l|l|l|l|l|l|}
\hline Source & $\begin{array}{l}\text { Type III Sum of } \\
\text { Squares }\end{array}$ & df & $\begin{array}{l}\text { Mean } \\
\text { Square }\end{array}$ & F & Sig. \\
\hline Corrected Model & $4.339 a$ & 5 & .868 & 3.340 & .006 \\
\hline Intercept & 19.576 & 1 & 19.576 & $\begin{array}{l}75.35 \\
4\end{array}$ & .000 \\
\hline gender & .003 & 1 & .003 & .010 & .919 \\
\hline Academic qualification & .683 & 1 & .683 & 2.631 & .106 \\
\hline Academic rank & .017 & 1 & .017 & .067 & .796 \\
\hline University & 1.473 & 1 & 1.473 & 5.669 & .018 \\
\hline Years of experience & .887 & 1 & .887 & 3.416 & .066 \\
\hline Error & 77.674 & 299 & .260 & & \\
\hline Total & 2677.895 & 305 & & & \\
\hline Corrected Total & 82.013 & 304 & & & \\
\hline
\end{tabular}

a. R Squared $=.053$ (Adjusted R Squared $=.037$ )

ANCOVA test is used to test the above hypothesis, it is found that $F$ value for ( university ) variable is significant at 0.05 level, whereas $F$ value for each of the rest variables is not significant at 0.05 level, that means there are no statistically significant differences in the level of job burnout among faculty members working in public and private universities in Jordan that are due to the variables of "gender, academic qualification, academic rank, university, and years of experience" for the sample members, except university variable. And these differences tend to increase in the (private) sample more than (public) sample, as shown in the following table:

Table 13: Means and Std. deviation for job burnout according to the University variable.

\begin{tabular}{|l|l|l|l|}
\hline University & Mean & $\mathrm{N}$ & Std. Deviation \\
\hline Public & 2.8379 & 116 & .48520 \\
\hline private & 2.9661 & 189 & .53474 \\
\hline Total & 2.9174 & 305 & .51940 \\
\hline
\end{tabular}

This result indicates that the perspective of the sample members (faculty members) on their level of job burnout is similar in all variables except for the university variable, as the perspective of the sample members in private universities on their job burnout is slightly higher than their counterparts in public universities. Although the difference is minor [as indicated in the arithmetic averages Table 13], it is statistically significant which means that it 
is a fundamental difference and has its importance. The perspective of faculty members in private universities may stem from their lack of job stability, as most of the faculty members in private universities work on annual or multi-year contracts, in addition to discrimination among them in terms of salaries, bonuses, incentives, and the interference of personal and social factors in facilitating tasks for some and not for others. It can be seen that many faculty members in private universities hold academic and administrative positions without any merit. Things differ in public universities, where faculty members feel more secure especially if they have open-ended contracts, and although personal and social factors also interfere, applying laws, regulations, instructions, and accountability happens in a better way, which justifies the perspective of the faculty members in not feeling job burnout.

\section{Recommendation}

Based on the findings of this study, researchers recommend the following:

First: both public and private universities should pay more attention to HRMPs, as the results showed that the level of these practices was moderate. This can be done by working on:

- Appointing the right people to work in this department to ensure that they do their job in the best possible way.

- Training employees on forward planning for the human resources management by engaging them in specialized courses and facilitating their acquaintance with prestigious universities that are experienced in this field.

- Monitoring the performance of human resources in terms of recruitment, selection, and appointment, in addition to providing them with the necessary information about the university's policy in this field.

- Involving employees in specialized training courses on evaluating faculty members and identifying the training needs for faculty members, and providing them with training in light of those needs.

- Giving the Human Resources Department more authority to enable them to retain faculty members, especially the distinguished ones.

Second: both public and private universities should pay more attention to faculty members, as the results showed that their level of job burnout was moderate. That can be done by working on providing a comfortable working environment academically and socially, paying attention to their personal matters, focusing on and showing their accomplishments, supporting the distinguished members, giving them the opportunity to express their opinions and share their ideas, and dealing with them fairly and reasonably.

\section{Conclusions}

This study dealt with three questions and three hypotheses focusing on the impact of HRMPs in public and private universities on job burnout among faculty members.

If universities want to improve and enhance the level of human resources departments' practices, they must pay attention to their methods of practicing their tasks, especially those related to faculty members, which lead to achieving a competitive advantage over other universities. Also, to achieve a competitive advantage, universities must pay attention to job burnout among faculty members and work hard to address all the causes related to it to keep it at a low level.

This research aimed to conduct a field study on the level at which human resources management in public and private universities in Jordan practice their tasks, as well as the 
level of job burnout among faculty members in these universities, in addition to the percentage of faculty members who would like to leave their work in these universities if they had better opportunities. This study also aimed to reveal whether HRMPs had a statistically significant effect on job burnout levels among faculty members in these universities.

Understanding the problem that this study dealt with might be an indication for future researchers who are interested in the same topic to conduct further investigations. Data for the study was collected from the research sample which was distributed to all public and private universities by using a questionnaire to measure all the variables that were included in the study.

Regarding the results of this study, it is clear that the level at which human resources management is practicing its tasks in public and private universities, and the level of job burnout among faculty members were moderate. It is also evident that the percentage of faculty members who wish to leave work in both public and private universities is close to $50 \%$, but it is slightly higher in private universities compared to public universities. The results and the multiple linear regression analysis show that there is a statistically significant effect of HRMPs on job burnout among faculty members in public and private universities.

It is concluded from the previous ideas that there is a remarkable similarity between public and private universities regarding this study subject. This may encourage researchers to conduct more research on this topic in Jordanian universities to reveal the reasons for the similarity despite the difference in the way and style of administration in these universities in general, and it may also encourage researchers to study other topics related to this subject in order to understand the universities' environment, whether public or private, in a better way and to further develop these universities.

\section{References}

Teir, R. A. A., \& Zhang, R. Q. (2016). The current practices of human resource management in higher education institutions in Palestine. Journal of Human Resources Management and Labor Studies, 4(1), 65-83.

Ahmed, D. (2019) The impact of human resources management practices in alleviating work pressures: a case study: Algeria telecom, Al-Bashaer Economic Journal, Vol. 4, No. 3

Al-Afif, A. H. (2018) The impact of human resource management practices on organizational commitment: an analytical study in the Jordanian ministry of culture, The Arab Journal of Management, Vol. 38, No. 4

Al-Azizi, M., \& Zaid, M. (2020) The Quality of Working Life and its Impact in Reduction of Job Burnout. Journal of Alandalus for Humanities and Social Sciences, 7( 27),6-43.

Al-Gharaibah,S. (2009) Human resources management practices and their impact on the application of overall quality management. an applied study on Jordanian hospitals. Unpublished doctoral thesis. Arab academy for banking and financial sciences.

Allui, A., \& Sahni, J. (2016). Strategic human resource management in higher education institutions: empirical evidence from Saudi. Procedia-Social and Behavioral Sciences, 235, 361-371.

Al-Talbani, N., Al-Agha, M., \& Saadallah, R. (2015). the relation between organizational factors and job burnout among faculty members in Palestinian universities in Gaza governorate. Al-Najah University Journal for Research (Humanities), 29 (4)

Amin, M., Ismail, W. K. W., Rasid, S. Z. A., \& Selemani, R. D. A. (2014). The impact of human resource management practices on performance: Evidence from a Public University. The TQM Journal. 
Kabunga, A. (2020). Prevalence of Burnout among University Academic Staff in Uganda; Does Gender Matter?.6(2:68),1-7.

Ashraf, S., Hussain, I., \& Malik, M. A. (2014). Making the Best of It? Human Resource Management Practices in Universities of Azad Jammu \& Kashmir. International Journal of Human Resource Studies, 4(4), 48.

Aslan, I., \& Bektaş, Ç. (2016). Analyzing Burnout Syndrome at Bingol University. BE-ci, 2016, 3rd.

Azeem, S. M. (2010). Personality hardiness, job involvement and job burnout among teachers. International journal of vocational and technical education, 2(3), 36-40.

Azeem, S. M., \& Nazir, N. A. (2008). A study of job burnout among university teachers. Psychology and Developing Societies, 20(1), 51-64.

Zaid, W. M. A. B. (2019). The Impact of Job Burnout on the Performance of Staff Member at King Abdul-Aziz University. International Journal of Business and Social Science, 10(4).

Daft, I. R. (2007) The new era of management. International Edition. Thomson Learning. U.K.

Dessler, G. (2011). Human resource management 12th Edition. Boston: Me Graw-Hill.

García-Arroyo, J. A., \& Segovia, A. O. (2019). Work overload and emotional exhaustion in university teachers: Moderating effects of coping styles. Universitas Psychologica, 18(2), 1-12.

Alsakarneh, A. A. A., Hong, S. C., Eneizan, B. M., \& AL-kharabsheh, K. A. (2019). Exploring the relationship between the emotional labor and performance in the Jordanian insurance industry. Current Psychology, 38(5), 1140-1151.

Fuster-Guillén, D., Jara-Jara, N., Ramírez-Asís, E., Maldonado-Leyva, H., Figueroa, R. P. N., \& Guzmán, A. G. (2019). Occupational Burnout on University Teachers through the Confirmatory Factorial Model. Journal of Educational Psychology-Propositos $y$ Representaciones, 7(3), 215-230.

Harem, H. (2020) Human resources management (an integrated framework), Amman, AlHamed Publishing and Distribution House and Library

Hijazi, H. A., \& Jawad, S. (2008) Organizations' Functions: A Managerial Approach to the Organizations of the 21st Century.(pp. 105-118) Alahlia for Publishing and Distribution, Amman- Jordan

Hong, E. N. C., Hao, L. Z., Kumar, R., Ramendran, C., \& Kadiresan, V. (2012). An effectiveness of human resource management practices on employee retention in institute of higher learning: A regression analysis. International journal of business research and management, 3(2), 60-79.

Ibrahim, S. B., \& Alwakeel, K. B. M. (2020) Human resources management practices and their impact on the quality of service in the kingdom of Saudi Arabia: by modeling the structural equation. Journal of Economic, Administrative and Legal Sciences. 4, ( 1 ).

Iqbal, M. Z., Arif, M. I., \& Abbas, F. (2011). HRM Practices in Public and Private Universities of Pakistan: A Comparative Study. International Education Studies, 4(4), 215-222.

Jia, L., Chudý, Š., Neumeister, P., \& Bo, Z. (2017). Study on the Job Burnout among University Teachers and Its Countermeasures. In Proceedings of the 2017 International Conference on E-Education, E-Business and E-Technology (pp. 9-12).

Kasasbeh, M. M., Al-Faouri, A. H., \& Al-Amian, M. S. (2010) The role of human resources management functions in the educated organization: a case study on talal abu-ghazaleh group of companies in Jordan. The Jordanian Journal of Business Administration, Vol. 6, No. 1 
Kebde, A., \& Gedfie, M. (2018). Burnout experience among public universities of Amhara regional state, Ethiopia. Indian Journal of Health \& Wellbeing, 9.

Khdour, N., Durrah, O., \& Harris, M. (2015). The effect of job burnout on employees' satisfaction: a comparison study between public universities and private universities in Jordan. Journal of Management Research, 7(4), 54-81.

Koohi, K. (2020). Explaining the impact of social capital, psychological capital, and organizational climate, and job experience on job burnout (case study: Faculty Members of Tabriz University). Journal of applied sociology, 31(2), 77-94.

Kosi, I., Opoku-Danso, A., \& Ofori, A. A. S. (2015). HRM practices and retention: An empirical study of senior staff of University of Cape Coast. International Journal of Technology Enhancements and Emerging Engineering Research, 3(11), 62-68.

Mansourian, Z., Moonaghi, K. H., Ashrafifard, H., \& AkbariLakeh, M. (2019). Faculty burnout: Does anyone think of that?. Future of Medical Education Journal, 9(3), 42-48.

Manzoor, S., Kazi, A. S., \& Aziz, F. (2019). Female University Teachers Burnout and its Association with their Demographic Variables. Pakistan Journal of Social and Clinical Psychology, 17(2), 56-61.

Maslach, C., \& Jackson, S. E. (1981). The measurement of experienced burnout. Journal of organizational behavior, 2(2), 99-113.

Mattjik, M., Akbar, M., \& Yasin, M. (2020). Managing human resources in a higher education institution: Managing the lecturers. International Journal of Scientific \& Technology Research, 2360.

Melhem, M. I. (2020) The Impact of organizational justice on job burnout in Palestinian public schools. Journal of the Islamic University of Economic and Administrative Studies, 28( 2),51-77.

Mondy, R. W., \& Mondy, J. (2012). Human resource management. 12th ed. Pearson Learning Solutions(pp. 81-97), U. K.

Mumtaz, A., Khan, I., Aslam, H. D., \& Ahmad, B. (2012). Impact of HR practices on job satisfaction of university teacher: evidence from universities in Pakistan. Industrial Engineering Letters, 1(3), 10-17.

Eneizan, B., Taamneh, M., Enaizan, O., Almaaitah, M., Ngah, A., \& Alsakarneh, A. (2021). Human resources practices and job satisfaction on customer satisfaction: The mediating role of quality of customer interaction in online call center. International Journal of Data and Network Science, 5(1), 11-18.

Noe, R. A., Hollenbeck, J. R., Gerhart, B., \& Wright, P. M. (2017). Human resource management: Gaining a competitive advantage. New York, NY: McGraw-Hill Education.

Ojokuku, R. M., \& Akanbi, F. K. (2015). Strategic Human Resource Management Practices and Performance In Nigerian Public Universities. Journal of Resources Development and Management, 10, 136-145.

Öztürk, G. (2013). Job burnout experienced by Turkish instructors of English working at state universities. International Online Journal of Educational Sciences, 5(3), 587-597.

Padilla, M. A., \& Thompson, J. N. (2016). Burning out faculty at doctoral research universities. Stress and Health, 32(5), 551-558.

Reddy, G. L., \& Poornima, R. (2012). Occupational stress and professional burnout of University teachers in South India. International Journal of Educational Planning \& Administration, 2(2), 109-124. 
Saifalislam, K. M., Osman, A., \& AlQudah, M. K. (2014). Human Resource Management Practices: Influence of recruitment and selection, and training and development on the organizational performance of the Jordanian Public University. organization, 3, 1-08873.

Sekaran, U., \& Bougie, R. (2016). Research methods for business: A skill building approach. John Wiley \& Sons.

Teles, R., Valle, A., Rodríguez, S., Piñeiro, I., \& Regueiro, B. (2020). Perceived stress and indicators of burnout in teachers at Portuguese higher education institutions (HEI). International journal of environmental research and public health, 17(9), 3248.

Toker, B. (2011). Burnout among university academicians: An empirical study on the universities of Turkey. 